\title{
Isolation, Characterization and Complementation Analysis of nirB Mutants of Escherichia coli Deficient Only in NADH-dependent Nitrite Reductase Activity
}

\author{
By HEATHER MACDONALD, N. R. POPE† AND J. A. COLE* \\ Department of Biochemistry, University of Birmingham, PO Box 363, Birmingham B15 2TT, UK
}

(Received 28 January 1985; revised 10 May 1985)

\begin{abstract}
Mutants have been isolated which lack NADH-dependent nitrite reductase activity but retain NADPH-dependent sulphite reductase and formate hydrogenlyase activities. These $\mathrm{NirB}^{-}$ strains synthesize cytochrome $c_{552}$ and grow normally on anaerobic glycerol-fumarate plates. The defects map in a gene, nir $B$, which is extremely close to $c y s G$, the gene order being $\operatorname{crp}, \operatorname{nir} B$, cys $G$, aroB. Complementation studies established that $n i r B^{+}$and $c y s G^{+}$can be expressed independently. The data strongly suggest that $\operatorname{nir} B$ is the structural gene for the $88 \mathrm{kDal}$ NADHdependent nitrite oxidoreductase apoprotein (EC 1.6.6.4).

The nir $B$ gene is apparently defective in the previously described nir $D$ mutant, LCB82. The nirH mutant, LCB197, was unable to use formate as electron donor for nitrite reduction, but $\mathrm{NADH}$-dependent nitrite reductase was extremely active in this strain and a normal content of cytochrome $c_{552}$ was detected. Strains carrying a nir E, nir $F$ or nir $G$ mutation gave normal rates of nitrite reduction by glucose, formate or $\mathrm{NADH}$.
\end{abstract}

\section{INTRODUCTION}

Anaerobic cultures of Escherichia coli $\mathrm{K} 12$ reduce nitrite rapidly to ammonia (Cole, 1978). The most active of the three enzymes involved in this reaction is an NADH-dependent nitrite reductase (EC 1.6.6.4) which, in a typical wild-type strain, contributes about $75 \%$ to the overall rate of nitrite reduction. It is a flavoprotein with a single type of polypeptide, $M_{\mathrm{r}} 88 \mathrm{kDal}$ (Coleman et al., 1978; Jackson et al., 1981). The prosthetic groups are a non-haem iron-sulphur cluster, sirohaem and loosely-bound FAD (Jackson et al., 1981). Synthesis of this NADHdependent enzyme, together with the membrane-bound formate-nitrite oxidoreductase which contributes about $20 \%$ to the overall rate of nitrite reduction (Abou-Jaoudé et al., 1977, 1979a), is repressed during aerobic growth. The third, NADPH-dependent nitrite reductase (EC 1.8.1.2), which functions physiologically as a sulphite reductase, is synthesized under both aerobic and anaerobic conditions, but is regulated by cysteine repression (Kemp et al., 1963).

In contrast to the progress that has been made in understanding the biochemistry of nitrite reduction, there is considerable confusion about the identity of structural and regulatory genes involved in the process. In previous reports from this laboratory we have described nir $A$ mutants (also called fnr and nirR mutants: Cole \& Ward, 1973; Lambden \& Guest, 1976; Chippaux et al., 1978) which are pleiotropically defective in both of the major pathways for nitrite reduction as well as in the synthesis of other anaerobically-induced reductases. The product of the nir $A^{+}$ $\left(f n r^{+}\right)$gene is a positive control protein which is required for transcription of many of the genes involved in anaerobic redox processes. We subsequently characterized a second group of mutations which mapped in the minute 74 region of the $E$. coli chromosome (Cole et al., 1980).

† Present address: PA Technology, Melbourn, Royston, Herts SG8 6DP, UK. 
All except one of these mutants were pleiotropically defective in the NADH-dependent nitrite reductase and the NADPH-dependent sulphite reductase: their $\mathrm{Cys}^{-} \mathrm{Nir}^{-}$phenotype and the mapping data suggested that they were cys $G$ mutants defective in the synthesis of sirohaem, a prosthetic group of both of these enzymes.

Amongst the previously characterized cysG mutants was a single $\mathrm{Cys}^{+} \mathrm{Nir}^{-}$strain [formerly called CB203 but now designated JCB203 to avoid confusion with similarly-designated strains from the collection of Dr Chippaux, (CNRS, Marseille, France)] which appeared to be deficient only in the NADH-dependent nitrite reductase activity. As the mutation in this strain mapped extremely close to the $c y s G$ gene, the possibility was considered that JCB203 was only partially defective in synthesis of the $c y s G$ product in such a way that sufficient sirohaem was synthesized to restore the $\mathrm{Cys}^{+}$phenotype, but insufficient to meet the increased demands for nitrite reduction during anaerobic growth (Cole et al., 1980). Other possibilities recognized were that strain JCB203 is defective in an independent gene for nitrite reduction which fortuitously maps close to $c y s G$, or is part of the $c y s G$ transcriptional unit. The product of such an independent gene could be the apoprotein for the NADH-dependent nitrite reductase or, alternatively, it could convert sirohaem to a modified form that is the prosthetic group of nitrite reductase. The primary aims of the experiments described in this paper were to determine whether there is a second gene in the $74 \mathrm{~min}$ region of the $E$. coli chromosome which is involved only in nitrite reduction and, if so, to characterize mutants in which it is defective.

Abou-Jaoudé et al. $(1978 a, b)$ have described a range of mutants which appeared to be defective in NADH-dependent nitrite reductase activity. A further aim was to characterize biochemically the $\mathrm{Nir}^{-} \mathrm{Cys}^{+}$mutants isolated in the two laboratories and to locate the structural gene for the NADH-dependent nitrite reductase apoprotein.

\section{METHODS}

Bacteria and media. Bacterial strains used in this study are listed in Table 1. E. coli cultures were derivatives of the K 12 strain. Media components were from Oxoid or from Lab M. Glycerol-fumarate plates (Lambden \& Guest, 1976) containing $1 \mathrm{~g}$ Casamino acids $\mathrm{l}^{-1}$ were incubated anaerobically in a Brewer's jar. Other media were either prepared according to the supplier's instructions, or have been described previously (Cole et al., 1974; Newman \& Cole, 1977).

Grow'th conditions, preparation of extracts and enzyme assays. These were as described by Cole et al. (1974) and by Newman \& Cole (1978) but with the following modifications. The concentration of nitrite during growth of mutants in 2 litre conical flasks was decreased from $5 \mathrm{~mm}$ to $2.5 \mathrm{~mm}$, and $0.4 \%(\mathrm{w} / \mathrm{v})$ maltose replaced glucose where noted. Washed bacteria were resuspended in $50 \mathrm{~mm}$ Tris $/ \mathrm{HCl}, 5 \mathrm{~mm}$-ascorbate, $5 \mathrm{~mm}$-EDTA, pH 8.0, before they were broken in a French pressure cell. Protein concentrations were determined by the microtannin procedure (Mejbaum-Katzenellenboger \& Dobryszycka, 1959). The oxidant for the NAD+-activated 'diaphorase' activity associated with NADH-nitrite oxidoreductase apoprotein was $0 \cdot 1 \mathrm{~mm}$-horse heart cytochrome $c$ (Sigma).

Inverted Durham tubes were used to monitor formate hydrogenlyase activity during anaerobic growth in rich media with $0.4 \%(\mathrm{w} / \mathrm{v})$ glucose as the fermentable substrate. Both Lennox broth (Miller, 1972) and nutrient broth were used interchangeably for these tests. Cysteine $\left(10 \mu \mathrm{g} \mathrm{ml}^{-1}\right)$ was added to cultures of cysteine auxotrophs.

Transposon Tn10 mutagenesis. The source of transposon Tn 10 was fresh stocks of bacteriophage $\lambda$ NK 370 (Table 1). These were generated by mixing three to five small, freshly-generated plaques with $0.2 \mathrm{ml}$ of an overnight culture of any suppressor-negative strain of $E$. coli (AB2847 or $\mathrm{HfrH}$ was normally used) in $\lambda$ broth ( $10 \mathrm{~g}$ tryptone, $2.5 \mathrm{~g} \mathrm{NaCl}^{-1}$ ). After $20 \mathrm{~min}$ at room temperature, $7.5 \mathrm{ml}$ molten $\lambda$ top agar ( $\lambda$ broth plus $6.5 \mathrm{~g}$ agar $\mathrm{l}^{-1}$ ) was added and the mixture was distributed to three $\lambda$ plates ( $\lambda$ broth plus $10 \mathrm{~g}$ agar $1^{-1}$ ).After about 10 (but less than 12) h at $37^{\circ} \mathrm{C}$, the phage were harvested by transferring the top agar to $2 \mathrm{ml} \mathrm{SM}(20 \mathrm{mM}-\mathrm{Tris} / \mathrm{HCl} \mathrm{pH} 7 \cdot 5,0 \cdot 1 \mathrm{M}-$ $\mathrm{NaCl}, 10 \mathrm{~mm}^{-\mathrm{MgSO}_{4}}$ ), homogenizing the suspension with $1 \mathrm{ml} \mathrm{CHCl}$ and centrifuging at $5000 \mathrm{~g}$ for $10 \mathrm{~min}$.

To induce $\mathrm{Tn} 10$ mutations, $2 \mathrm{ml}$ cultures of the desired host were grown with aeration to mid-exponential phase in $\lambda$ ym broth $(\lambda$ broth plus $0.2 \%, w / v$, maltose and $0.01 \%, w / v$, yeast extract), harvested by centrifugation and resuspended in $0.1 \mathrm{ml} \lambda$ ym broth. The $\lambda$ suspension was diluted 10 -fold and $0.1 \mathrm{ml}$ of undiluted and diluted phage were added to separate tubes of recipient bacteria. After $1 \mathrm{~h}$ at $37^{\circ} \mathrm{C}$, the contents of each tube were spread onto a Lennox agar plate containing $15 \mu \mathrm{g}$ tetracycline $\mathrm{ml}^{-1}$ and $2.5 \mathrm{~mm}$-sodium pyrophosphate. Tetracycline-resistant colonies formed after $24 \mathrm{~h}$ at $37^{\circ} \mathrm{C}$.

It was essential to prepare all media within $24 \mathrm{~h}$ of use, to generate stocks from fresh plaques and to use the stocks on the day they were prepared. For this reason, $\lambda$ stocks were not titred before use. Nevertheless, results were extremely variable and few, if any, tetracycline-resistant colonies were obtained from about half of the infection experiments. 
Table 1. Strains used and their source

Strain

AB3 12

$\mathrm{AB} 2847$

CGSC 4248

CGSC 4315

CGSC $4248 \mathrm{~F}^{\prime} 141$

DB6659

$\mathrm{HfrH}$

$\mathrm{JCB} 203+$

JCB $312 \uparrow$

JCB401†

JCB406

JCB407

JM72

LCB $82 \dagger$

LCB $84 \dagger$

LCB85t

LCB $190+$

LCB $197 \dagger$

LCB900

MAL103

OR75Ch15

RVChl1

W3102
Genotype

thr-I leu-6 thi-1 lacZ4 rpsL8 supE44-Hfr point of origin 12

aro $B$ malA

argG6 metBI his-1 leu-6 recAl mtl-2 xyl-7 malAl gal-6 lacYI rpsL104 tonA2 ts. $x-1$ SupE 44

Prototrophic Hfr malB supE

CGSC 4248/ $\mathrm{F}^{\prime}$ argG ${ }^{+}$rpsL $L^{+}$aroB ${ }^{+} \mathrm{malA}^{+}$

srl-300::Tn 10 recA56 ilv-318 thr-300 thi-1 spc-300 rel-1

Prototroph

nir-203 (now nirB203)

$\mathrm{AB} 2847 \mathrm{Mal}^{+}$cysG 72

CGSC4315 chl-401

JCB401 cysG406: : Tn5

JCB401 cysG407: : Tn5

cysG72 thr leu pro his argC thi lac gal mal xyl rpsL nirD82 thr-1 leu-6 lac Yl tonA22 thi-1

ana-1 rpsL

As LCB82, but nirF

As LCB82, but nirE

As LCB82, but $\operatorname{nir} G$

As LCB82, but nirH

As LCB82, but nir ${ }^{+}$parent

Mu cts dl $\left(\mathrm{Ap}^{\mathrm{R}}\right.$ lac) araB:: Mu cts

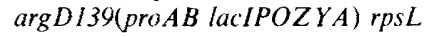
Prototrophic $\mathrm{Hfr}$

Prototrophic $\mathrm{F}^{-}$

cysG3102
Source* or reference

CGSC

CGSC

Acridine orange curing of CGSC4248 F'141

CGSC

CGSC

Laboratory stocks

Laboratory stocks

Cole et al. (1980)

$\mathrm{P} 1$ transduction; JM72 as donor and AB2847

as recipient

CGSC4315 spontaneously resistant

anaerobically to $10 \mathrm{~mm}$-chlorate

Tn 5 mutagenesis with $\mathrm{F}^{\prime} 141:: \operatorname{Tn} 5$

Tn5 mutagenesis with $\mathrm{F}^{\prime} 141:: \operatorname{Tn} 5$

M. C. Jones-Mortimer

M. Chippaux (Abou-Jaoudé et al., $1979 b$ )

M. Chippaux (Pascal et al., 1981)

M. Chippaux (Abou-Jaoudé et al., $1978 b)$

M. Casadaban

Cole et al. (1980)

Strain RV spontaneously resistent to $10 \mathrm{~mm}$ chlorate during anaerobic growth

M. G. Marinus

* CGSC strains received from B. Bachmann, E. coli Genetic Stock Center, Yale University, New Haven, Conn., USA. Other addresses are: M. C. Jones-Mortimer, Department of Biochemistry, Cambridge University, UK : M. Chippaux, Laboratoire de Chimie Bacterienne, CNRS, Marseille, France; M. Casadaban, Department of Biophysics and Theoretical Biology, University of Chicago, Ill., USA; M. G. Marinus, Department of Pharmacology, University of Massachusetts Medical School, Worcester, Mass., USA.

+ Strains isolated in different laboratories (including nitrite reductase-deficient mutants) were formerly designated CB; to minimize confusion, extra letters have been added to these strain designations by agreement between the two laboratories.

Mutagenesis with the Casadaban phage $M u d l\left(A p^{R} l a c\right)$. The source of bacteriophage Mudl( $\left.\operatorname{Ap}^{R} l a c\right)$ was a mixed lysate of $\mathrm{Mu} c \mathrm{cts}$ and $\mathrm{Mu} \mathrm{dl}\left(\mathrm{Ap}^{\mathrm{R}}\right.$ lac $)$ generated from the double lysogen MAL103. It was used as described by Casadaban \& Cohen (1979). After infection of the parent strain, $0.3 \mathrm{ml}$ cultures were incubated for 1 to $2 \mathrm{~h}$ at $30{ }^{\circ} \mathrm{C}$ with $2 \mathrm{ml}$ Lennox broth to allow expression of ampicillin resistance and plated onto nutrient agar supplemented with $25 \mu \mathrm{g}$ ampicillin $\mathrm{ml}^{-1}$. Colonies appeared after $36 \mathrm{~h}$ at $30^{\circ} \mathrm{C}$.

Temperature stabilization of $M u d I\left(A p^{R}\right.$ lac) fusion strains. Ampicillin-resistant mutants were grown to saturation at $30^{\circ} \mathrm{C}$ in $1 \mathrm{ml}$ Lennox broth and diluted 50 -fold into $5 \mathrm{ml}$ fresh Lennox broth. After $2 \mathrm{~h}$ at $30^{\circ} \mathrm{C}$, the cultures were aerated at $42^{\circ} \mathrm{C}$ for $20 \mathrm{~min}$ and grown to saturation at $37^{\circ} \mathrm{C}$. Serial dilutions were then plated onto nutrient agar and incubated at $37^{\circ} \mathrm{C}$. Colonies from suitable plates were replica plated onto selective media to screen for loss of markers of interest.

Other genetic methods. Nitrosoguanidine mutagenesis and the isolation of mutants defective in anaerobic growth with nitrite as sole nitrogen source were described by Cole \& Ward (1973). Two cycles of penicillin enrichment were used before survivors of mutagenesis were tested for their ability to reduce nitrite. Random Tn 10 or $\mathrm{Mud} 1\left(\mathrm{Ap}^{\mathrm{R}} l a c\right)$-induced mutants were screened for ability to reduce nitrite by the spot test procedure without enrichment (Cole \& Ward, 1973). 
Table 2. Characterization of $\mathrm{NirD}^{-}, \mathrm{NirE}^{-}, \mathrm{NirF}^{-}, \mathrm{NirG}^{-}$and $\mathrm{NirH}^{-}$strains

\begin{tabular}{|c|c|c|c|c|c|}
\hline \multirow[b]{2}{*}{ Strain } & \multirow[b]{2}{*}{ Genotype } & \multicolumn{2}{|c|}{$\begin{array}{c}\text { Nitrite reduction } \\
\text { by bacterial suspensions } \\
\text { [nmol nitrite reduced } \\
\left.\min ^{-1}(\mathrm{mg} \text { bacterial dry } \mathrm{wt})^{-1}\right]\end{array}$} & \multirow{2}{*}{$\begin{array}{l}\text { NADH-dependent } \\
\text { nitrite reductase } \\
{[\text { nmol NADH oxidized }} \\
\left.\text { min }^{-1}(\text { mg protein })^{-1}\right]\end{array}$} & \multirow{2}{*}{$\begin{array}{c}\text { Cytochrome } c_{552} \\
\text { content } \\
{\left[\mathrm{pmol}(\mathrm{mg} \text { protein })^{-1}\right]}\end{array}$} \\
\hline & & $\begin{array}{l}\text { Glucose- } \\
\text { dependent }\end{array}$ & $\begin{array}{l}\text { Formate- } \\
\text { dependent }\end{array}$ & & \\
\hline LCB 900 & nir $^{+}$parent & 48 & 19 & 166 & 76 \\
\hline LCB82 & $\operatorname{nir} D$ & 32 & 19 & $<10$ & 174 \\
\hline LCB84 & $n i r F$ & 15 & 6 & 774 & 94 \\
\hline LCB 85 & nirE & 18 & 10 & 225 & 66 \\
\hline LCB 190 & $\operatorname{nir} G$ & 33 & 15 & 403 & 109 \\
\hline LCB 197 & nirH & 74 & $<2$ & 1530 & 169 \\
\hline
\end{tabular}

Transposon $\mathrm{Tn} 5$ was introduced into a derivative of the Hfr strain CGSC4315 on the plasmid $\mathrm{F}^{\prime} 141$. After mating, bacteria were harvested by centrifugation, resuspended in Lennox broth plus $0.4 \%(\mathrm{w} / \mathrm{v})$ glucose and incubated for $30 \mathrm{~min}$ with aeration at $37^{\circ} \mathrm{C}$ to ensure expression of kanamycin resistance. Kanamycin was then added to $25 \mu \mathrm{g} \mathrm{ml}^{-1}$ and cultures were grown to saturation to ensure loss of the $\mathrm{F}^{\prime}$ plasmid due to incompatibility with the F factor resident in the chromosome. Strains JCB406 and JCB407 are independently isolated $\mathrm{Kan}^{\mathrm{R}} \mathrm{Cys}^{-} \mathrm{Nir}^{-}$derivatives which were purified by single colony isolation.

Bacteriophage Plkc was used for transduction experiments (Miller, 1972).

The $\operatorname{rec} A$ mutation was transferred to $\mathrm{F}^{-}$strains by mating them with the Hfr strain DB6659 which carries a $\operatorname{rec} A$ allele and $\mathrm{Tn} 10$ inserted into the nearby $s r l$ gene (Bachmann, 1983). Tetracycline-resistant colonies were selected and screened for increased sensitivity to UV light (Miller, 1972).

\section{RESULTS AND DISCUSSION}

All of the nitrite reductase-deficient mutants previously isolated in this laboratory were, with one exception, also pleiotropically defective for one or more other reductases (Cole et al., 1980). In contrast, Abou-Jaoudé et al. $(1978,1979 b)$ described mutants with lesions in nirD, E, F, $G$ and $H$ which apparently were specifically deficient in nitrite reduction. Dr Marc Chippaux kindly provided us with a representative mutant from each group for more detailed biochemical characterization.

After overnight growth in media supplemented with nitrite, suspensions of the nirD strain LCB82 reduced nitrite when formate was the electron donor (Table 2). The glucose-dependent rate of nitrite reduction was less than that of the parental strain and no NADH-dependent nitrite reductase activity was detected in bacterial extracts (Table 2). In contrast to the nirD mutant, the nirH strain LCB197 reduced nitrite rapidly with glucose as the electron donor, but formate-dependent nitrite reductase was inactive. The specific activity of the NADHdependent nitrite reductase in the nir $H$ mutant was higher than in any other strain we have tested and was approximately twice that of the chlorate-resistant mutants which are constitutive for nitrite reductase synthesis during anaerobic growth (compare Table 2 with Jackson et al., 1981). Furthermore, the $88 \mathrm{kDal}$ apoprotein of nitrite reductase was readily detected in unfractionated extracts of this mutant by SDS-PAGE (data not shown). Very little formatedependent nitrite reductase activity was detected with the nirH mutant, but contrary to the earlier reports (Abou-Jaoudé et al., 1979b; Pascal et al., 1981), cytochrome $c_{552}$ was readily detected in bacterial extracts (Fig. 1). We conclude that the nir $H$ gene is required for electron transfer from formate to nitrite rather than for NADH-dependent nitrite reduction.

Formate was an effective electron donor for nitrite reduction by suspensions of strains LCB85 (nirE), LCB84 (nirF) and LCB190 (nirG). As the NADH-dependent nitrite reductase was also very active in these strains, we conclude that they are defective in anaerobic glucose metabolism rather than specifically in nitrite reduction. This conclusion is consistent with the lower rate of glucose-dependent nitrite reduction by suspensions of these mutants than by the nirH mutant (Table 2). 


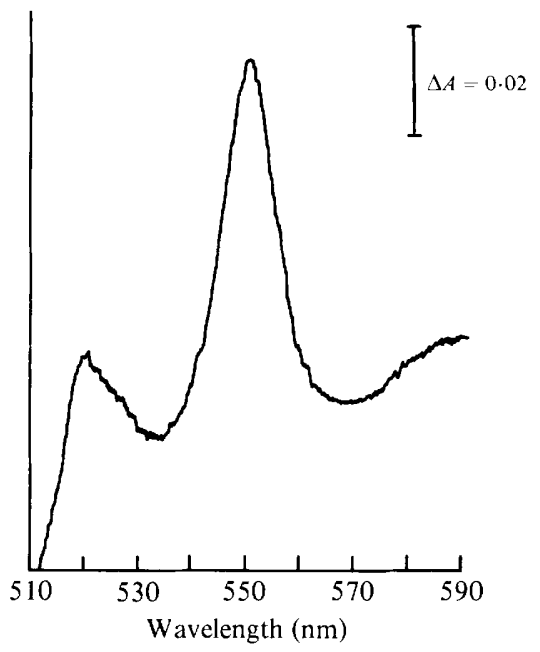

Fig. 1. Difference spectrum showing the presence of cytochrome $c_{552}$ in soluble proteins from the nirH mutant LCB197. Sodium dithionite was added to reduce proteins in the sample cuvette. The reference sample was oxidized with a few grains of potassium ferricyanide. The spectrum was recorded at room temperature and the protein concentration was $16.5 \mathrm{mg} \mathrm{ml}^{-1}$.

In summary, only two of the mutant classes described by Abou-Jaoudé et al. (1978a) were deficient in their ability to reduce nitrite and only the nirD strain was defective in NADHdependent nitrite reductase activity. The phenotype of LCB82 was identical to that of strain JCB203, but although both of these lesions were reported to map in the $c r p-c y s G$ region of the $E$. coli chromosome, data for co-transduction with $\operatorname{aroB}^{+}$suggest that they might be defective in different genes (compare Cole et al., 1980, with Abou-Jaoudé et al., 1979b). To resolve this point a systematic search was made for other mutants specifically deficient in NADH-dependent nitrite reductase activity.

\section{Isolation of mutants defective only in $\mathrm{NADH}$-dependent nitrite reduction}

Three mutagenesis techniques and five different parental strains were used to generate a wide range of nitrite reductase deficient mutants. The parents included the nir $H$ mutant LCB 197 and two chlorate-resistant mutants, all of which synthesize high activities of NADH-dependent nitrite reductase but cannot use formate to reduce nitrite. Two $\mathrm{Hfr}$ strains were also used to facilitate transfer of interesting mutations to different genetic backgrounds. Mutants defective in nitrite reduction were purified by single colony isolation, tested for formate hydrogenlyase activity and used as donors in bacteriophage P1-mediated transduction with the $\operatorname{aro} B$ mutant AB2847 or its derivative AB2847 $\mathrm{Arg}^{-}:: \mu_{\mathrm{ts}}$ as recipient (Table 3). Only one of 25 new mutants, JCB313, was $\mathrm{Cys}^{-}$. The $39 \%$ co-transduction of both the $\mathrm{Nir}^{-}$and the $\mathrm{Cys}^{-}$phenotypes with $\mathrm{Aro}^{+}$indicated that JCB313 carries a cysG::Mu dl $\left(\mathrm{Ap}^{\mathrm{R}}\right.$ lac $)$ insertion.

The remaining mutants fell into two groups which we provisionally designated nirA ( fnr) or nir $B$ (Table 3). All six Tn 10 mutants were deficient in formate hydrogenlyase activity and were unable to grow anaerobically on glycerol-fumarate plates. The tetracycline-resistance determinant was not co-transducible with $\operatorname{aroB}^{+}$(Table 3) or with cys $^{+}$. We conclude that these are nir $\boldsymbol{A}$ ( $f n r)$ mutants. The most interesting aspect of these experiments was our failure to generate $\operatorname{Tn} 10$ insertion mutations in either the $c y s G$ or the nir $B$ genes.

In contrast to $\mathrm{Tn} 10$ mutagenesis, nitrosoguanidine and $\mathrm{Mu} \mathrm{d} l\left(\mathrm{Ap}^{\mathrm{R}} l a c\right)$ mutagenesis resulted in the isolation of a series of mutants defective only in NADH-dependent nitrite reductase activity. The retention of formate hydrogenlyase activity, the $\mathrm{Cys}^{+}$phenotype, the ability to grow anaerobically on glycerol-fumarate plates and the 15 to $45 \%$ co-transduction of the nitrite reduction defects with aro $B^{+}$were consistent with these strains being defective in a nitrite 
Table 3. Recently-isolated mutants deficient in NADH-dependent nitrite reductase activity

\begin{tabular}{|c|c|c|c|c|c|}
\hline Mutant & Parent & Mutagen & $\begin{array}{c}\text { Formate } \\
\text { hydrogenlyase* }\end{array}$ & Other relevant information & $\begin{array}{l}\text { Suggeste } \\
\text { genotyp }\end{array}$ \\
\hline JCB301 & RVChll & $\mathrm{Mu} \operatorname{dl}\left(\mathrm{Ap}^{\mathrm{R}}\right.$ lac $)$ & - & $\begin{array}{l}\mathrm{Nir}^{-} \mathrm{Amp}^{\mathrm{R}} 20 \% \text { co-transducible } \\
\text { with aroB } B^{+}\end{array}$ & $\operatorname{nir} B$ \\
\hline JCB302 & RVChll & $\mathrm{Mu} \operatorname{dl}\left(\mathrm{Ap}^{\mathrm{R}} l a c\right)$ & - & $\begin{array}{l}\text { Derivative isolated with deletion } \\
\text { into cysG (see later) }\end{array}$ & $\operatorname{nir} B$ \\
\hline JCB303 & RVChll & $\mathrm{Mu} d l\left(\mathrm{Ap}^{\mathrm{R}} l a c\right)$ & - & As $\mathrm{JCB} 302$ & $\operatorname{nir} B$ \\
\hline JCB304 & RVChll & $\mathrm{Mu} \mathrm{d} l\left(\mathrm{Ap}^{\mathrm{R}}\right.$ lac $)$ & - & $\begin{array}{l}\mathrm{Nir}^{-} \mathrm{Amp}^{\mathrm{R}} \text { co-transducible with } \\
\operatorname{aroB^{+}}\end{array}$ & nir $B$ \\
\hline JCB305 & RVChll & $\mathrm{Mu} \operatorname{d} l\left(\mathrm{Ap}^{\mathrm{R}} l a c\right)$ & - & As JCB304 & $\operatorname{nir} B$ \\
\hline JCB306 & RVChll & $\mathrm{Mu} \mathrm{d} 1\left(\mathrm{Ap}^{\mathrm{R}}\right.$ lac $)$ & - & As JCB304 & $\operatorname{nir} B$ \\
\hline JCB307 & OR75Chl5 & NG & - & $\begin{array}{l}\mathrm{Nir}^{-}>90 \% \text { co-transducible with } \\
\text { cys } G^{+} ; 45 \% \text { co-transducible with } \\
\text { aro } B^{+}\end{array}$ & $\operatorname{nir} B$ \\
\hline JCB308 & OR75Chl5 & NG & - & $\begin{array}{l}\mathrm{Nir}^{-} \text {not co-transducible with } \\
\text { aro } B^{+} ; \text {defective cytochrome } c_{552} \\
\text { synthesis }\end{array}$ & $\operatorname{nir} A$ \\
\hline ЈСB309 & $\mathrm{HfrH}$ & NG & + & $\begin{array}{l}\mathrm{Nir}^{-}>90 \% \text { co-transducible with } \\
\text { cysG } G^{+} ; 24 \% \text { co-transducible with } \\
\text { aro } B^{+}\end{array}$ & $\operatorname{nir} B$ \\
\hline $\mathrm{JCB} 310$ & $\mathrm{HfrH}$ & NG & + & $\begin{array}{l}\mathrm{Nir}^{-}>90 \% \text { co-transducible with } \\
\text { cysG }{ }^{+} ; 28 \% \text { co-transducible with } \\
\text { aro } B^{+}\end{array}$ & $\operatorname{nir} B$ \\
\hline JCB311 & $\mathrm{HfrH}$ & $\mathrm{Mu} d l\left(\mathrm{Ap}^{\mathrm{R}} l a c\right)$ & + & $\mathrm{Amp}^{\mathrm{R}}$ co-transducible with $\operatorname{aro} B^{+}$ & $\operatorname{nir} B$ \\
\hline JCB313 & $\mathrm{HfrH}$ & $\mathrm{Mu} \operatorname{dl}\left(\mathrm{Ap}^{\mathrm{R}}\right.$ lac $)$ & + & $\begin{array}{l}\text { Also } \text { Cys }^{-} ; \text {Amp }^{R} \text { Cys }^{-} 100 \% \\
\text { co-transducible with } \mathrm{Nir}^{-} ; 39 \% \\
\text { with } \text { aro } B^{+}\end{array}$ & cys $G$ \\
\hline JCB315 & LCB197 nirH & $\operatorname{Tn} I 0$ & - & $\begin{array}{l}\mathrm{Nir}^{-} \text {phenotype complemented by } \\
\text { the } f n r^{+} \text {plasmid pCH } 21\end{array}$ & $\operatorname{nir} A$ \\
\hline JCB316 & LCB 197 nirH & $\operatorname{Tn} I 0$ & - & As JCB315 & $\operatorname{nir} A$ \\
\hline JCB317 & LCB197 nirH & $\operatorname{Tn} I 0$ & - & - & $\operatorname{nir} A$ \\
\hline JCB318 & LCB197 nirH & $\operatorname{Tn} 10$ & - & - & $\operatorname{nir} A$ \\
\hline JCB319 & LCB197 nirH & $\operatorname{Tn} 10$ & - & 一 & $\operatorname{nir} A$ \\
\hline JCB220 & LCBi97 nirH & $\operatorname{Tn} 10$ & - & $\begin{array}{l}\mathrm{Tet}^{\mathrm{R}} \mathrm{Nir}^{-} \text {phenotype not } \\
\text { co-transducible with aro } B^{+}\end{array}$ & $\operatorname{nir} A$ \\
\hline JCB382 & AB312 & $\mathrm{Mu} d \mathrm{l}\left(\mathrm{Ap}^{\mathrm{R}} l a c\right)$ & + & - & $\operatorname{nir} B$ \\
\hline JCB383 & AB312 & $\mathrm{Mu} d l\left(\mathrm{Ap}^{\mathrm{R}} l a c\right)$ & + & $\begin{array}{l}\text { Derivative isolated with deletion } \\
\text { extending into cys } G\end{array}$ & $\operatorname{nir} B$ \\
\hline JCB384 & AB312 & $\mathrm{Mu} \mathrm{dl}\left(\mathrm{Ap}^{\mathrm{R}} l a c\right)$ & + & As JCB383 & $\operatorname{nir} B$ \\
\hline JCB385 & $\mathrm{AB} 312$ & $\mathrm{Mudl}\left(\mathrm{Ap}^{\mathrm{R}} l a c\right)$ & + & $A m p^{R}$ co-transducible with aro $B^{+}$ & $\operatorname{nir} B$ \\
\hline JCB386 & AB312 & $\mathrm{Mudl}\left(\mathrm{Ap}^{\mathrm{R}}\right.$ lac $)$ & + & As JCB385 & $\operatorname{nir} B$ \\
\hline JCB387 & AB312 & $\mathrm{Mu} d \mathrm{l}\left(\mathrm{Ap}^{\mathrm{R}} l a c\right)$ & + & As JCB385 & $\operatorname{nir} B$ \\
\hline JCB388 & AB 312 & $\mathrm{Mu} \mathrm{dl}\left(\mathrm{Ap}^{\mathrm{R}} l a c\right)$ & + & As JCB385 & $\operatorname{nir} B$ \\
\hline
\end{tabular}

* Formate hydrogenlyase is inactive in chlorate-resistent strains due to loss of normal molybdenum incorporation into the formate dehydrogenase component. This test is therefore useful only for mutants derived from chlorate-sensitive strains.

NG, Nitrosoguanidine.

Table 4. Temperature-resistant derivatives of $M u d I\left(A p^{R}\right.$ lac $)$

\begin{tabular}{|c|c|c|}
\hline $\begin{array}{l}\text { Original temperature- } \\
\text { sensitive mutant }\end{array}$ & $\begin{array}{c}\text { Phenotype of temperature- } \\
\text { sensitive parent }\end{array}$ & $\begin{array}{l}\text { Phenotype of temperature } \\
\text { resistant derivative }\end{array}$ \\
\hline JCB301 & $\mathrm{Ap}^{\mathrm{R}} \mathrm{Lac}^{+} \mathrm{Nir}^{-} \mathrm{Cys}^{+}$ & $\mathrm{Ap}^{\mathrm{S}} \mathrm{Lac}^{-} \mathrm{Nir}^{-} \mathrm{Cys}^{+}$ \\
\hline JCB302 & $\mathrm{Ap}^{\mathrm{R}} \mathrm{Lac}^{+} \mathrm{Nir}^{-} \mathrm{Cys}^{+}$ & $\mathrm{Ap}^{\mathrm{S}} \mathrm{Lac}^{+} \mathrm{Nir}^{-} \mathrm{Cys}^{-}$ \\
\hline $\mathrm{JCB} 303$ & $\mathrm{Ap}^{k} \mathrm{Lac}^{+} \mathrm{Nir}^{-} \mathrm{Cys}^{+}$ & $\mathrm{Ap}^{\mathrm{S}} \mathrm{Lac}^{-} \mathrm{Nir}^{-} \mathrm{Cys}^{+}$ \\
\hline JCB383 & $\mathrm{Ap}^{\mathrm{R}} \mathrm{Lac}^{-} \mathrm{Nir}^{-} \mathrm{Cys}^{+}$ & $\begin{array}{l}\mathrm{Ap}^{\mathrm{s}} \mathrm{Lac}^{-} \mathrm{Nir}^{-} \mathrm{Cys}^{-} \\
\mathrm{Ap}^{\mathrm{S}} \mathrm{Lac}^{-} \mathrm{Nir}^{-} \mathrm{Cys} \mathrm{s}^{+} \\
\mathrm{Ap}^{\mathrm{s}} \mathrm{Lac}^{-} \mathrm{Nir}^{-} \mathrm{Cys}^{-}\end{array}$ \\
\hline
\end{tabular}


reductase gene other than $c y s G$ but located in the 74 min region of the chromosome. The phenotypes of these mutants were similar to that of the previously described strains JCB203 and LCB82.

\section{Biochemical characterization of mutants deficient in NADH-dependent nitrite reductase activity}

All of the mutants tentatively designated nir $B$, together with their parental strains, were grown anaerobically in rich media supplemented with glucose and nitrite. Glucose-dependent and formate-dependent rates of nitrite reduction by bacterial suspensions and NADHdependent nitrite reductase activities of extracts were determined. The sirohaem-deficient apoprotein of purified NADH-nitrite oxidoreductase can still catalyse the reduction of mammalian cytochrome $c$ by NADH and a characteristic feature of this activity is its activation by $\mathrm{NAD}^{+}$. Mutants defective in the synthesis of the sirohaem prosthetic group should retain this activity, but absence of an $\mathrm{NADH}^{+}$-activated cytochrome $c$ reductase should be a diagnostic characteristic of strains unable to synthesize the nitrite reductase apoprotein; this activity was also determined.

All of the newly-isolated nir $B$ mutants reduced nitrite more slowly than the parental strain with glucose as the electron donor, but nitrite reduction by formate was unaffected or, if anything, slightly more rapid. Neither NADH-dependent nitrite oxidoreductase nor $\mathrm{NAD}^{+}-$ activated cytochrome $c$ reductase activity was detected in any of these mutants or in the nirD strain LCB82. Surprisingly, an NAD ${ }^{+}$-activated cytochrome $c$ reductase was readily detected in the previously-described mutant JCB203: this result would be consistent with nirB being the structural gene for the NADH-nitrite oxidoreductase apoprotein if the nirB203 protein retains normal binding domains for $\mathrm{NADH}, \mathrm{NAD}^{+}$and cytochrome $c$ but lacks the sirohaem or nitritebinding domains (Jackson et al., 1982).

All of the $\operatorname{nir} B$ mutants grew well on minimal agar unsupplemented with cysteine, indicating that the $c y s G^{+}$gene was intact and expressed.

\section{Temperature stabilization of the $M u d I\left(A p^{R}\right.$ lac $)$ fusion strains}

Ampicillin-sensitive derivatives of many of the operon fusion mutants were isolated after heat induction. Some of these temperature-resistant derivatives had also lost either the ability to grow without cysteine, or the $\mathrm{Lac}^{+}$phenotype controlled by the nirB promoter, or both (Table 4). The alteration of three or four of these phenotypes (including temperature-sensitivity) by a single event was assumed to be caused by a deletion of chromosomal DNA during aberrant excision of the $\mathrm{Mudl}\left(\mathrm{Ap}^{\mathrm{R}} l a c\right)$ prophage. Loss of only one or two characteristics could result from either a transpositional deletion or inversion event. The phenotypes of the various derivatives are consistent with nir $B$ and $c y s G$ being independent genes located close to each other on the $E$. coli chromosome. They establish that no essential genes or biosynthetic determinants are located between $c y s G$ and nirB, but do not establish whether the two genes are contiguous or are expressed independently.

\section{Location of the nirB gene by transduction}

All of the nirB mutations together with several of the deletion mutations in temperatureresistant derivatives of $\operatorname{nir} B:: \mathrm{Mudl}\left(\mathrm{Ap}^{\mathrm{R}}\right.$ lac $)$ strains were transferred to the $\mathrm{Aro}^{-}$mutant $\mathrm{AB} 2847$. The $\mathrm{Arg}^{-}$derivative of $\mathrm{AB} 2847$ carrying a $\mathrm{Mu}_{\mathrm{ts}}$ prophage was the recipient for $\mathrm{Mu} d \mathrm{l}\left(\mathrm{Ap}^{\mathrm{R}}\right.$ lac $)$ insertion mutations.

In each experiment, between $15 \%$ and $45 \%$ of the $\mathrm{Aro}^{+}$transductants were $\mathrm{Nir}^{-}$. When ampicillin-resistant transductants were selected, all were $\mathrm{Nir}^{-}$but at most $20 \%$ were $\mathrm{Aro}^{+}$. The presence of the $\mathrm{Mudl}\left(\mathrm{Ap}^{\mathrm{R}}\right.$ lac $)$ prophage in these donor strains decreased the apparent cotransduction frequency, so map distances cannot be calculated from such data.

Three of the nirB mutations, the nirD mutation in strain LCB82 and four cys $G$ mutations were transferred to AB2847 and over $100 \mathrm{Aro}^{+}$transductants were scored for their Nir, Cys, Mal and, where appropriate, kanamycin resistance phenotypes. As previously reported by Cole et al. (1980), the $\mathrm{Cys}^{-}$and $\mathrm{Nir}^{-}$phenotypes of $c y s G$ strains were $100 \%$ cotransducible. This provided further evidence that the $\mathrm{Cys}^{-}$and $\mathrm{Nir}^{-}$phenotypes are due to a single mutation and that $\mathrm{Tn} 5$ is 
Table 5. Cotransduction frequencies for the transfer of $\mathrm{Nir}^{-}$mutations with aroB ${ }^{+}$

\begin{tabular}{|c|c|c|c|c|c|c|c|c|}
\hline \multicolumn{2}{|c|}{ Donor } & \multicolumn{5}{|c|}{ No. of transductants with the phenotype: } & \multirow{2}{*}{$\begin{array}{l}\text { Cotransduction } \\
\text { frequency }(\%) \\
\mathrm{Aro}^{+} \mathrm{Nir}^{-} / \mathrm{Aro}^{+}\end{array}$} & \multirow{2}{*}{$\begin{array}{c}\text { Designation of } \\
\text { Aro }^{+} \mathrm{Mal}^{-} \mathrm{Nir} \\
\text { derivative }\end{array}$} \\
\hline Strain & Genotype & $\mathrm{Aro}^{+}$ & $\mathrm{Aro}^{+} \mathrm{Nir}^{-}$ & $\mathrm{Aro}^{+} \mathrm{Mal}^{+}$ & $\mathrm{Aro}^{+}$ & $\mathrm{Nir}^{-} \mathrm{Mal}^{+}$ & & \\
\hline \multirow[t]{2}{*}{ JCB406 } & $\operatorname{cys} G 406$ & 108 & 36 & 30 & & () & 33 & JCB421 \\
\hline & & 108 & 36 & - & & - & 33 & \\
\hline \multirow[t]{2}{*}{ JCB407 } & $\operatorname{cys} 407$ & 108 & 41 & 30 & & 3 & 38 & JCB422 \\
\hline & & 108 & 30 & - & & - & 28 & \\
\hline \multirow[t]{2}{*}{ W3102 } & cysG3102 & 108 & 7 & 44 & & 1 & 7 & JCB423 \\
\hline & & 108 & 17 & - & & - & 16 & - \\
\hline \multirow[t]{2}{*}{$\mathrm{JM} 72$} & $c y s G 72$ & 108 & 21 & 44 & & 6 & 22 & JCB424 \\
\hline & & 105 & 32 & $\ldots$ & & - & 31 & - \\
\hline \multirow[t]{2}{*}{ JCB309 } & $\operatorname{nir} B 309$ & 100 & 24 & 58 & & 10 & 24 & JCB425 \\
\hline & & 103 & 35 & - & & - & 34 & - \\
\hline \multirow[t]{2}{*}{ JCB307 } & nir $B 307$ & 105 & 24 & 64 & & 5 & 30 & JCB426 \\
\hline & & 107 & 34 & - & & - & 32 & .. \\
\hline \multirow[t]{2}{*}{ JCB203 } & $\operatorname{nir} B 203$ & 108 & 25 & 56 & & 7 & 23 & $\mathrm{JCB} 427$ \\
\hline & & 108 & 40 & - & & - & 37 & - \\
\hline LCB82 & nir $D 82$ & 108 & 21 & - & & 0 & 20 & JCB428 \\
\hline
\end{tabular}

Table 6. Transduction data for determining the relative position of cysG72 and the nir mutations

Strain CB312 (cysG72 aroB) was transduced to $\mathrm{Cys}^{+}$using bacteriophage $\mathrm{P} 1$ which had been propagated on the donor strains. After purification transductants were screened for their Aro ${ }^{+}$ phenotype by replica plating, and for their $\mathrm{Nir}^{+}$phenotype by the spot testing procedure.

\begin{tabular}{|c|c|c|c|c|c|c|c|c|}
\hline \multicolumn{2}{|c|}{ Donor } & \multicolumn{5}{|c|}{ No. of transductants with the phenotype: } & \multirow{2}{*}{$\begin{array}{c}\text { Recombination } \\
\text { frequency }(\%) \\
\mathrm{Cys}^{+} \mathrm{Nir}^{+} / \mathrm{Cys}^{+}\end{array}$} & \multirow{2}{*}{$\begin{array}{l}\text { Map distance } \\
\text { (min) }\end{array}$} \\
\hline Strain & Genotype & $\mathrm{Cys}^{+}$ & Cys ${ }^{+} \mathrm{Nir}^{+}$ & Cys $^{+}$ & $\mathrm{Nir}^{+} \mathrm{Aro}^{-}$ & $\mathrm{Cys}^{+} \mathrm{Aro}^{+}$ & & \\
\hline CB425 & nir $B 309$ & 141 & 16 & & 5 & 95 & $11 \cdot 8$ & $0 \cdot 078$ \\
\hline CB426 & nir B307 & 144 & 15 & & 7 & 91 & $10 \cdot 4$ & 0.072 \\
\hline CB427 & nir B203 & 119 & 5 & & 2 & 101 & $4 \cdot 2$ & 0.028 \\
\hline CB428 & nirD82 & 108 & 17 & & 6 & 94 & $12 \cdot 3$ & 0.086 \\
\hline
\end{tabular}

inserted in the cysG gene in strains W3102, JCB406 and JCB407. All of the nirB and the cysG mutations were 16 to $38 \%$ co-transducible with aro B $^{+}$and few, if any, $\mathrm{Aro}^{+} \mathrm{Mal}^{+}$transductants were also $\mathrm{Nir}^{-}$(Table 5). This indicates that each of these $\mathrm{Nir}^{-}$mutations is located on the opposite side of aroB to malA at about minute 73.5 on the E. coli linkage map (Wu, 1966; Bachmann, 1983).

From each transduction an $\mathrm{Aro}^{+} \mathrm{Mal}^{-} \mathrm{Nir}^{-}\left(\mathrm{Cys}^{-}\right)$colony was purified for biochemical characterization and for use in strain constructions for complementation analysis. These strains were designated JCB421 to JCB428.

The relative order of the eight $\mathrm{Nir}^{-}$mutations used for the previous experiments was determined by three-point crosses in which an $\operatorname{aroB}$ cysG72 strain, JCB312, was transduced to $\mathrm{Cys}^{+}$with phage which had been propagated on the $\mathrm{Nir}^{-}$strains JCB421 to JCB423 and JCB425 to JCB428. Both $\mathrm{Cys}^{+} \mathrm{Nir}^{+} \mathrm{Aro}^{+}$and $\mathrm{Cys}^{+} \mathrm{Nir}^{-} \mathrm{Aro}^{-}$transductants were obtained when a nirB or the nir $D$ strain was the donor, indicating that the gene order is nir $B(D)$-cysG72-aroB (Table 6). A tentative genetic map has been constructed based on the recombination frequencies between the donor $\mathrm{Nir}^{-}$and the cysG72 mutations (Fig. 2).

A very low frequency of recombination was also detected when any of the three $c y s G:: \operatorname{Tn} 5$ strains was the donor and the cysG72 strain was the recipient (Table 7). All of the Cys ${ }^{+}$colonies were $\mathrm{Nir}^{+}$. All of the $\mathrm{Cys}^{+}$transductants were also $\mathrm{Aro}^{-}$, so each of the cys $G:: \operatorname{Tn} 5$ mutations is located between the cysG72 and $\operatorname{aroB}$ mutations. In these experiments, the number of $\mathrm{Aro}^{+}$ transductants was also determined so that the recombination frequency between the donor and recipient $\mathrm{Cys}^{-}$mutation could be calculated relative to an internal control. In each case the very low recombination frequency implied a map distance of less than $0.01 \mathrm{~min}$. The only conclusions 


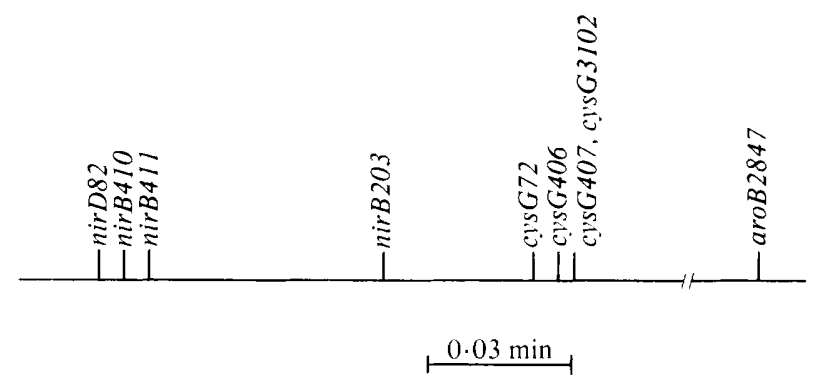

Fig. 2. Linkage map of the $\mathrm{Nir}^{-}$mutations located around minute 74 of the $E$. coli chromosome. The positions of individual mutations were determined relative to the cysG72 allele by three-point transductional crosses. The relative positions with respect to other mutations have not been determined, but the map illustrates the arrangement of the $c y s G:: \operatorname{Tn} 5$, nirB and 'nirD82' mutations relative to $\operatorname{cis} G 72$.

Table 7. Transduction data for determining the relative positions of cysG72 and the cys mutations

Strain $C B 312$ (as $G 72$ aroB $)$ was transduced to $\mathrm{Cys}^{+}$or $\mathrm{Aro}^{+}$using bacteriophage $\mathrm{Pl}$ which had been propagated on the donor strains. Cys ${ }^{+}$transductants were purified and their Aro phenotype was determined by replica plating.

\begin{tabular}{|c|c|c|c|c|c|c|}
\hline \multicolumn{2}{|c|}{$\overbrace{}^{\text {Donor }}$} & \multicolumn{3}{|c|}{$\begin{array}{l}\text { No. of transductants } \\
\text { with the phenotype: }\end{array}$} & \multirow{2}{*}{$\begin{array}{c}\text { Recombination } \\
\text { frequency }(\%) \\
\mathrm{Cys}^{+} / \mathrm{Aro}^{+}\end{array}$} & \multirow{2}{*}{$\begin{array}{l}\text { Map distancet } \\
(\mathrm{min})\end{array}$} \\
\hline Strain & Genotype & $\mathrm{Cys}^{+}$ & $\mathrm{Cys}^{+} \mathrm{Aro}^{-}$ & $\mathrm{Aro}^{+*}$ & & \\
\hline CB421 & css 406 & 93 & 93 & 10280 & 0.9 & 0.006 \\
\hline CB422 & $\cos G 407$ & 59 & 59 & 4770 & $1 \cdot 2$ & 0.008 \\
\hline $\mathrm{CB} 423$ & $\operatorname{crs} G 3102$ & 59 & 59 & 4910 & $1 \cdot 2$ & $0 \cdot 008$ \\
\hline
\end{tabular}

* $\mathrm{Aro}^{+}$was selected independently of the Cys ${ }^{+}$selection.

+ Subject to large error (see text).

drawn from these results are that the four $\mathrm{Cys}^{-} \mathrm{Nir}^{-}$mutations are extremely close together and that mutations which produce the $\mathrm{Nir}^{-} \mathrm{Cys}^{+}$and $\mathrm{Nir}^{-} \mathrm{Cys}^{-}$phenotypes are arranged in two clusters. This clustering of mutations which cause similar phenotypes suggests the existence of at least two genes and supports the $c y s G$ and $\operatorname{nir} B$ designations that were previously made on the basis of phenotype.

The phenotypes caused by the various $\operatorname{nir} B$ and $c y s G$ mutations were confirmed by determining the rate of nitrite reduction by formate, the NADH-nitrite oxidoreductase activity and the concentration of cytochrome $c_{552}$ in cell extracts of the isogenic strains JCB421 to JCB427 (Table 8). The nirB and the nirD82 mutations resulted in total loss of NADH-dependent nitrite reductase activity but nitrite reduction by formate and synthesis of cytochrome $c_{552}$ were essentially unaffected. The cisG strains were also deficient in NADPH-dependent sulphite reductase activity, as expected (Table 8 ).

\section{Complementation analysis of the nirB, nirD and cys loci}

A set of spontaneously arising $\mathrm{F}^{\prime}$ plasmids carrying $c y s G$, nir $B$ or the nirD82 mutation was constructed by the procedures summarized in Table 9 . These plasmids were then transferred by conjugation into nirB recA or $c y s G$ rec $A$ recipients. $\mathrm{Mal}^{+}$merodiploids were purified by single colony isolation and tested for their ability to reduce nitrite after overnight growth with maltose and nitrite. When the $\mathrm{F}^{\prime}$ plasmid carried transposon $\mathrm{Tn} 5$, kanamycin was also included in the growth medium to select for retention of the plasmid. 

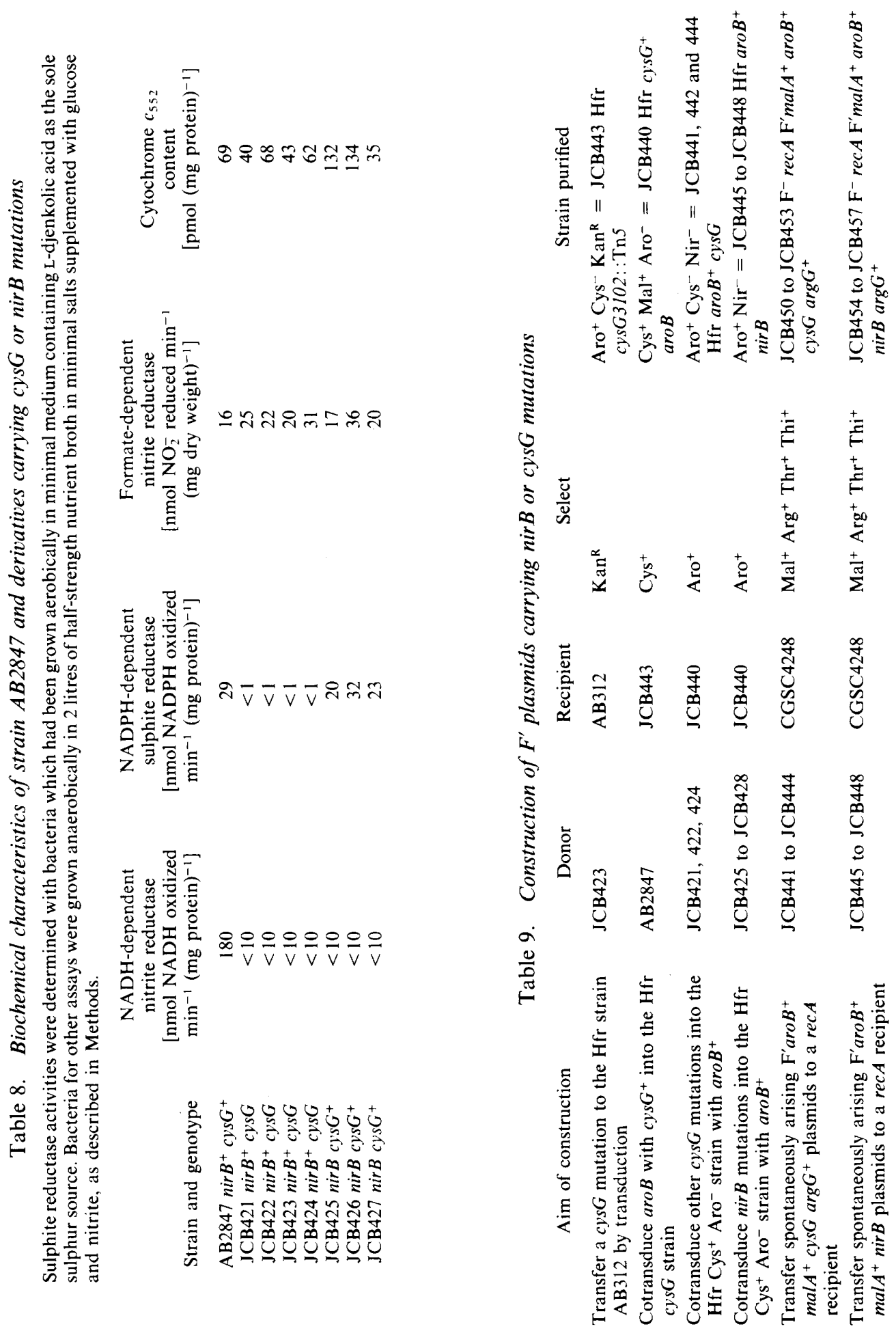
Table 10. Complementation analysis of the nir B and cysG loci

Merodiploid strains were grown with maltose as the fermentable carbon source to maintain selection for retention of the $\mathrm{F}^{\prime}$ plasmid and, where appropriate, $20 \mu \mathrm{g}$ kanamycin $\mathrm{ml}^{-1}$ was also added. Strains JCB431 to JCB437 are srl::TnIOrecA derivatives of JCB421 to JCB427 (parental strain AB2847; see Tables 5 and 8 ).

\begin{tabular}{|c|c|c|c|c|}
\hline \multirow[b]{2}{*}{ Host } & \multirow[b]{2}{*}{$F^{\prime}$ plasmid } & \multirow{2}{*}{$\begin{array}{l}\text { NADH-dependent } \\
\text { nitrite reductase } \\
\text { [nmol NADH oxidized } \\
\left.\text { min }^{-1}(\text { mg protein })^{-1}\right]\end{array}$} & \multicolumn{2}{|c|}{$\begin{array}{c}\text { Cytochrome } c \text { reductase } \\
{[\text { nmol cyto } c \text { reduced }} \\
\left.\min ^{-1}(\mathrm{mg} \text { protein })^{-1}\right]\end{array}$} \\
\hline & & & $-\mathrm{NAD}^{+}$ & $+\mathrm{NAD}^{+}$ \\
\hline JCB431 cysG406:: $\operatorname{Tn} 5$ & $\begin{array}{l}\text { None } \\
\text { F'nir }^{\prime} c y s^{+} \\
\text {F'nirB203 }^{\prime} \text { F'nirB130 }\end{array}$ & $\begin{array}{r}<10 \\
370 \\
13 \\
<10\end{array}$ & $\begin{array}{r}940 \\
1610 \\
1120 \\
134\end{array}$ & $\begin{array}{r}2500 \\
4160 \\
2890 \\
134\end{array}$ \\
\hline JCB433 cysG3102: :Tn5 & $\begin{array}{l}\text { None } \\
\mathrm{F}^{\prime} \text { nir }{ }^{+} \text {cys } \\
\mathrm{F}^{\prime} \text { nir B203 } \\
\mathrm{F}^{\prime} \text { nirB } B 130\end{array}$ & $\begin{array}{l}<10 \\
532 \\
<10 \\
<10\end{array}$ & $\begin{array}{l}1220 \\
\mathrm{ND} \\
\mathrm{ND} \\
\mathrm{ND}\end{array}$ & $\begin{array}{l}2260 \\
\text { ND } \\
\text { ND } \\
\text { ND }\end{array}$ \\
\hline JCB435 nirB309 & $\begin{array}{l}\text { None } \\
\mathrm{F}^{\prime} \text { nir }{ }^{+} \text {cys } \\
\mathrm{F}^{\prime} \text { cysG } 406:: \operatorname{Tn} 5 \\
\mathrm{~F}^{\prime} \text { cysG3102::Tn5 } \\
\mathrm{F}^{\prime} \text { cysG72 } \\
\mathrm{F}^{\prime} \text { nirB203 }\end{array}$ & $\begin{array}{r}<10 \\
43 \\
179 \\
192 \\
<10 \\
<10\end{array}$ & $\begin{array}{l}280 \\
345 \\
515 \\
461 \\
122 \\
790\end{array}$ & $\begin{array}{r}220 \\
690 \\
1095 \\
1040 \\
101 \\
1440\end{array}$ \\
\hline $\mathrm{JCB} 437$ nirB203 & $\begin{array}{l}\text { None } \\
\mathrm{F}^{\prime} \text { nir }{ }^{+} \text {cys }^{+} \\
\mathrm{F}^{\prime} c y s G 406:: \operatorname{Tn} 5 \\
\mathrm{~F}^{\prime} \text { cysG3102::Tn5 } \\
\mathrm{F}^{\prime} \text { cysG72 }\end{array}$ & $\begin{array}{r}<10 \\
187 \\
225 \\
296 \\
18\end{array}$ & $\begin{array}{r}2860 \\
\vdots 910 \\
2490 \\
2320 \\
818\end{array}$ & $\begin{array}{l}7240 \\
2010 \\
5990 \\
5880 \\
2370\end{array}$ \\
\hline
\end{tabular}

The wild-type plasmid $\mathrm{F}^{\prime} 141$ complemented the defects in both $\operatorname{cys} G$ and nirB mutants, confirming that both types of mutation are recessive in trans (Table 10). The results obtained with $\mathrm{F}^{\prime}$ plasmids carrying mutations were not entirely as expected, because although $c y s G: \operatorname{Tn} 5$ plasmids complemented $\mathrm{NirB}^{-}$strains, no complementation was observed with $\mathrm{F}^{\prime}$ cysG72 (Table 10). Plasmids carrying nir $B$ mutations and an intact $c y s G$ gene restored the $\mathrm{Cys}^{+}$phenotype of cys $G$ mutants but the merodiploids were still $\mathrm{Nir}^{-}$. This indicates that although the $c y s G^{+}$gene on the $\mathrm{F}^{\prime}$ plasmid was expressed, the nir $B^{+}$gene on the chromosome was not.

The $\mathrm{F}^{\prime}$ cys $G:: \operatorname{Tn} 5$ plasmids used for the complementation experiments were extremely unstable and it was essential to maintain selective pressure for plasmid retention during overnight growth in 2 litre cultures. Even so, only between $24 \%$ and $63 \%$ of the bacteria assayed were $\mathrm{Mal}^{+}$, and these $\mathrm{Mal}^{+}$colonies generated both $\mathrm{Mal}^{+}$and $\mathrm{Mal}^{-}$colonies when restreaked onto MacConkey-maltose agar. In contrast, the $\mathrm{Mal}^{+}$phenotype of merodiploids carrying the $F^{\prime}$ cys $G 72$ plasmid was stably maintained.

The F'nir B203 plasmid partially restored an $\mathrm{NAD}^{+}$-activated cytochrome $c$ reductase, but not nitrite reductase, activity to the nirB mutant JCB435. This supports the suggestion that nitrite reductase apoprotein, in a form inactive for nitrite reduction, is synthesized by strains carrying the nirB203 mutation. Furthermore, either the gene coding for this protein or a gene essential for its synthesis is located in the minute 69 to 75 region of the $E$. coli chromosome because the $F^{\prime}$ plasmid used carries genes from $\arg G$ at minute 69 to $\mathrm{mal} A$ at minute 75 .

None of the nirB mutations or the nirD82 mutation was complemented by a nirB or the nirD82 plasmid; similarly, none of the $\mathrm{F}^{\prime}$ plasmids carrying $c y s G$ mutations complemented either the $\mathrm{Cys}^{-}$or the $\mathrm{Nir}^{-}$phenotypes of chromosomal cys $G$ mutations. We therefore conclude that the $\mathrm{NirB}^{-}$and $\mathrm{NirD}^{-}$phenotypes are due to mutations in a single gene, nirB, which is close to but independent from the $c y s G$ gene.

In summary, the data presented in this paper establish that two genes essential for NADHdependent nitrite reduction are located in the 74 minute region of the $E$. coli chromosome. 
Although they map extremely close together, their expression is at least partially independent. The nir $B$ gene is located between $\operatorname{crp}$ and $c y s G$. The large number of mutants isolated with defects in nir $B$ and our failure to isolate other mutants deficient only in NADH-dependent nitrite oxidoreductase activity with lesions mapping elsewhere on the E. coli chromosome strongly suggest that nir $B$ is the structural gene for the $88 \mathrm{kDal}$ nitrite reductase apoprotein. The formal possibility remains, however, the nir $B$ encodes a positive control protein or some other function that is essential for nitrite reductase synthesis.

The authors are grateful to N. Kleckner, D. Bottstein, M. Casadaban, M. G. Marinus, J. R. Guest, C. Higgins and M. Chippaux for supplying strains and protocols for their use. H.M. was supported by an SERC Research Studentship, and N.R.P was supported by an NERC Research Studentship.

\section{REFERENCES}

Abou-Jaoudé, A., Chippaux, M., Pascal, M.-C. \& CASSE, F. (1977). Formate: a new electron donor for nitrite reduction in Escherichia coli $\mathrm{K} 12$. Biochemical and Biophysical Research Communications 78, 579583.

Abou-Jaoudé, A., Pascal, M.-C., Casse, F. \& ChippauX, M. (1978a). Isolation and phenotypes of mutants from Escherichia coli $\mathrm{K} 12$ defective in nitrite reductase activity. FEMS Microbiology Letters 3, 235-239.

Abou-JaOudé, A., Lepelletier, M., Ratouchniak, J., Chippaux, M. \& Pascal, M.-C. (1978b). Nitrite reduction in Escherichia coli: genetic analysis of nir mutants. Molecular and General Genetics 167, 113118 .

abou-Jaoudé, A., Chippaux, M. \& Pascal, M.-C. $(1979 a)$. Formate-nitrite reduction in Escherichia coli K12. 1. Physiological study of the system. European Journal of Biochemistry 95, 309-314.

Abou-Jaoudé, A., Pascal, M.-C. \& Chippaux, M. $(1979 b)$. Formate-nitrite reduction in Escherichia coli K 12. 2. Identification of components involved in the electron transfer. European Journal of Biochemistry 95, 315-321.

BaCHMANN, B. J. (1983). Linkage map of Escherichia coli K 12, edition 7. Microbiological Reviews 47, 180230.

Casadaban, M. J. \& Cohen, S. N. (1979). Lactose genes fused to exogenous promoters in one step using a Mu-lac bacteriophage: in vivo probe for transcriptional control sequences. Proceedings of the National Academy of Sciences of the United States of America 76, $4530-4533$

Chippaux, M., Giudici, D., Abou-Jaoudé, A., Casse, F. \& PASCAL, M.-C. (1978). Mutation leading to total lack of nitrite reductase activity in Escherichia coli K12. Molecular and General Genetics 160, 225-229.

Cole, J. A. (1978). The rapid accumulation of large quantities of ammonia during nitrite reduction by Escherichia coli. FEMS Microbiology Letters 4, 327329.

COLE, J. A. \& WARD, F. B. (1973). Nitrite reductasedeficient mutants of Escherichia coli K12. Journal of General Microbiology 76, 21-29.

Cole, J. A., Coleman, K. J., Compton, B. E., Kavanagh, B. M. \& Keevil, C. W. (1974). Nitrite and ammonia assimilation by anaerobic continuous cultures of Escherichia coli. Journal of General Microbiology 85, 11-22.

Cole, J. A., Newman, B. M. \& White, P. (1980). Biochemical and genetic characterization of nir $B$ mutants of Escherichia coli $\mathrm{K} 12$ pleiotropically defective in nitrite and sulphite reduction. Journal of General Microbiology 120, 475-483.

Coleman, K. J., Cornish-Bowden, A. \& Cole, J. A. (1978). Purification and properties of nitrite reductase from Escherichia coli K12. Biochemical Journal 175, 483-493.

JaCKSON, R. H., CoRnish-Bowden, A. \& Cole, J. A. (1981). Prosthetic groups of the NADH-dependent nitrite reductase from Escherichia coli K 12. Biochemical Journal 193, 861-867.

J ACKSON, R. H., Cole, J. A. \& CoRnish-Bowden, A. (1982). The steady state kinetics of the NADHdependent nitrite reductase from Escherichia coli K 12: the reduction of single-electron acceptors. Biochemical Journal 203, 505-510.

Kemp, J. D., AtKinson, D. E., Ehret, A. \& LAzZaRINI, R. A. (1963). Evidence for the identity of the nicotinamide adenine dinucleotide phosphatespecific sulphite and nitrite reductases of Escherichia coli. Journal of Biological Chemistry 238, 3466-3471.

LAmbden, P. R. \& Guest, J. R. (1976). Mutants of Escherichia coli $\mathrm{K} 12$ unable to use fumarate as an anaerobic electron acceptor. Journal of General Microbiology 97, 145-160.

Metjbaum-Katzenellenboger, W. \& DrobrysZYCKA, W. H. (1959). New method for quantitative determination of serum proteins separated by paper electrophoresis. Clinica chimica acta 4, 515-522.

Miller, J. H. (1972). Experiments in Molecular Genetics. Cold Spring Harbor, New York: Cold Spring Harbor Laboratory.

Newman, B. M. \& Cole, J. A. (1977). Lack of a regulatory function for glutamine synthetase protein in the synthesis of glutamate dehydrogenase and nitrite reductase in Escherichia coli K12. Journal of General Microbiology 98, 369-377.

Newman, B. M. \& Cole, J. A. (1978). The chromosomal location and pleiotropic effects of mutations in the $\operatorname{irA}^{+}$gene of Escherichia coli K12: the essential role of nir $A^{+}$in nitrite reduction and in other anaerobic redox reactions. Journal of General Microbiology 106, 1-12.

Pascal, M.-C., Chippaux, M., Abou-Jaoudé, A., BlaschkowsKi, H. P. \& KNAPPE, J. (1981). Mutants of Escherichia coli $\mathrm{K} 12$ with defects in anaerobic pyruvate metabolism. Journal of General Microbiology 124, 35-42.

WU, T. T. (1966). A model for three-point analysis of random general transduction. Genetics 54, 405-410. 